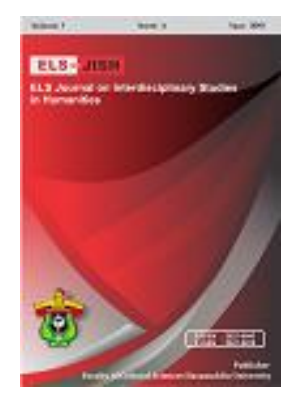

ELS-JISH

ELS Journal on Interdisciplinary Studies on Humanities

Volume 2 Issue 3, 2019

ISSN (print) : 2621-0843

ISSN (online) : 2621-0835

Homepage : http://journal.unhas.ac.id/index.php/jish

\title{
The Ability of Students in Using English Adverbs at State Politechnic of Pangkajene Kepulauan
}

\author{
Yusri Muhammad Yusuf, ${ }^{1}$ Bj Pratiwi ${ }^{2}$ \\ 1 yusrimuhammadyusuf@yahoo.co.id
}

\begin{abstract}
This research is about the ability of the first year students of the Agribusiness Department in using English adverb. Based on it, it is present two problems namely: 1) How is the ability of the first year Students of the Agribusiness department in using English adverb? 2) What are the factors influencing the students' ability in using adverbs?. To answer the question above, the writer collects data by using test and questionnaire. The data collected through the instruments were analyzed by using descriptive analysis. The result of the research shows that some of the students in Agricultural State Polytechnic of Pangkep were less interested in English, especially in using adverbs. The first year Students of the Agribusiness department can only be classified into poor. This achievement was influenced by the low of the students' interest and the lack of the English books.
\end{abstract}

Keywords: English Pragmatic Competence, English Grammar Competence, IELTS

How to cite: Malik, E. (2019). The English Pragmatic Competence of Indonesian English Speakers. ELS Journal on Interdisciplinary Studies in Humanities, 2 (3), 431-438

\section{Introduction}

English as one of the foreign languages is very important to learn, therefore, the government of Indonesia has put it in the curriculum as the first foreign language from junior high schools up to Universities. Furthermore, we can see that most of the scientific books are written in English. Therefore, learning this language is very important for the students. The important thing that we have to know is that learning a language is not an easy job because it needs many skills and abilities, including learning Adverbs.

An adverb as one of the parts of speech has a complex problem. Sometimes the students cannot put them in accurate position in sentences. They find difficult to learn.

English as the first international language plays a very important role to development of science and technology. Without knowing English, a student cannot read the scientific books which are written in English.

\footnotetext{
${ }^{1,}$ Politeknik Negeri Pangkajene Kepulauan, Indonesia

${ }^{2}$ SMAN 1 Soppeng, Indonesia
} 
For the importance of English, the students have to study hard. On the other hand, the English teachers must teach their best in teaching English. They have to teach as well as possible in order that their students can easily understand what they teach.

As we know that there are many parts in English sentence namely adverbs. One who wants to express his or her opinion need to know about it. That is why the important of adverbs as part of English sentence must be paid attention seriously. Since how can one state well what he or she wants to say without knowing it.

The English lecturers of Agricultural Polytechnic of Pangkep before teaching adverbs to their students have to master the materials of adverbs and the teaching strategies. Without mastering the materials to be taught, it is impossible to teach the material well. Therefore, both the materials and teaching strategies have to be mastered by the teacher if he or she wants to teach well. Those aspects can only be mastered by the teacher if he or she has good planning and preparation.

Although most of the English teachers have taught their best, but the result of the English teaching is still far away from the target. Most of the students of the junior high school and senior high school who have finished their studies are still very poor in English; moreover, they almost do not know anything about English. Most of them do not know adverbs and do not know how to use them. Realizing the fact above, the writer wants to conduct a research that studies about the teaching adverbs to the first year student of Agribusiness department.

Based on the statement above, the writer tries to formulate the following problems:

a. How is the ability of the first-year students of the Agribusiness department in using adverbs?

b. What are the factors influencing the students' ability in using adverbs?

This research was carried out to know the ability of first year students of Agribusiness department in using adverbs and to find out the factors influencing the student's ability in using adverbs.

The outcome of the research is expected to be useful and helpful information for the English teachers at Agribusiness department, especially in improving the quality of teaching and learning process about using adverbs. For students, it is expected to be useful developing their capability in using adverbs.

\section{Method}

The instruments were done by the writer there is two kind, namely test and questionnaire, the data collected through the test is about ability to use English adverb, and the data collected through the questionnaire is about the factors which might have influence the students' achievement.

Before coming to the analysis, the writer gives first score to each students' answer and he also gives code of the questionnaire that have been done by the students, the students' raw score is put it the table. 


\section{Results}

\subsection{Analysis of the data collected through the test.}

To analyze the data collected through the test it is very important to find out firstly the rate percentage of the students score before coming to this, it is necessary to give the classification of the score used, the classification of the score categorized into seven levels, as follow:

9,6 to 10 is classified as excellent

8,6 to 9,5 is classified as very good

7,6 to 8,5 is classified as good

6,6 to 7,5 is classified as fairly good

5,9 to 6,5 is classified as fair

3,6 to 5,5 is classified as poor

0,0 to 3,5 is classified as very poor (Depdikbud, 1995)

Table 1. Data Collected Through the test

\begin{tabular}{|c|c|c|c|}
\hline $\begin{array}{l}\text { Number } \\
\text { respondent }\end{array}$ & $\begin{array}{l}\text { Number } \\
\text { Items }\end{array}$ & $\begin{array}{l}\text { Number of } \\
\text { Correct Answer }\end{array}$ & Score \\
\hline 1 & 20 & 5 & 2,5 \\
\hline 2 & 20 & 10 & 5 \\
\hline 3 & 20 & 5 & 2,5 \\
\hline 4 & 20 & 3 & 1,5 \\
\hline 5 & 20 & 12 & 6 \\
\hline 6 & 20 & 12 & 6 \\
\hline 7 & 20 & 11 & 5,5 \\
\hline 8 & 20 & 12 & 6 \\
\hline 9 & 20 & 6 & 3 \\
\hline 10 & 20 & 4 & 2 \\
\hline 11 & 20 & 11 & 5,5 \\
\hline 12 & 20 & 15 & 7,5 \\
\hline 13 & 20 & 12 & 6 \\
\hline 14 & 20 & 10 & 5 \\
\hline 15 & 20 & 9 & 4,5 \\
\hline 16 & 20 & 5 & 2,5 \\
\hline 17 & 20 & 17 & 8,5 \\
\hline 18 & 20 & 14 & 7 \\
\hline 19 & 20 & 7 & 3,5 \\
\hline 20 & 20 & 7 & 3,5 \\
\hline 21 & 20 & 13 & 6,5 \\
\hline 22 & 20 & 15 & 6,5 \\
\hline 23 & 20 & 9 & 4,5 \\
\hline 24 & 20 & 8 & 4 \\
\hline 25 & 20 & 8 & 4 \\
\hline 26 & 20 & 3 & 1,5 \\
\hline 27 & 20 & 8 & 4 \\
\hline 28 & 20 & 11 & 5,5 \\
\hline 29 & 20 & 7 & 3,5 \\
\hline 30 & 20 & 13 & 6,5 \\
\hline 31 & 20 & 8 & 4 \\
\hline 32 & 20 & 4 & 2 \\
\hline
\end{tabular}


ISSN: (E) 2621-0835, (P) 2621-0843

\begin{tabular}{llll}
\hline 33 & 20 & 8 & 4 \\
34 & 20 & 11 & 5,5 \\
35 & 20 & 14 & 7 \\
36 & 20 & 10 & 5 \\
37 & 20 & 6 & 3 \\
38 & 20 & 8 & 4 \\
38 & 20 & 16 & 8 \\
40 & 20 & 7 & 3,5 \\
\hline Total & & 372 & 186 \\
\hline
\end{tabular}

Based on the table above, the total score of the students is 186 and the total number of the student who have been researched comes to 40 individuals the find the mean score of student's abilities in using English adverb the previously determined formula is used namely:

$$
\bar{X}=\frac{\Sigma X}{N}
$$

The calculation of the formula is shown below:

Calculation:

$$
\begin{aligned}
& \bar{X}=\frac{180}{40} \\
& \bar{X}=4,65
\end{aligned}
$$

Based on the result of the calculation above it can be inferred that ability of the first year students of Agribusiness State Polytechnic of Pangkajene Kepulauanin using adverb is still low. This can be proved from the result of the calculation above that the mean score of the students is only 4,65 . based in the classification of score is categorized as a poor.

Data percentage of the students' score

Table 2. Data Percentage of the Students Score in Using English Adverb

\begin{tabular}{lllll}
\hline No & Classification & Score & Frequency & Percentage \\
\hline 1 & Excellent & $9,6-10$ & 0 & 0 \\
2 & Very Good & $8,6-9,5$ & 0 & 0 \\
3 & Good & $7,6-8,5$ & 2 & $5 \%$ \\
4 & Fairly Good & $6,6-7,5$ & 4 & $10 \%$ \\
5 & Fair & $5,6-6,5$ & 6 & $15 \%$ \\
6 & Poor & $3,6-5,5$ & 15 & $13,5 \%$ \\
7 & Very Poor & $0,0-3,5$ & 13 & $32,5 \%$ \\
\hline & Total & & 40 & $100 \%$ \\
\hline
\end{tabular}

The table indicates that must of the first year students of Agribusiness State Polytechnic of Pangkajene Kepulauan in using English adverb got undesirable score, as we see in the above none at them reached the excellent and very good classification. (32,5\%) who got very poor score, and fairly good score. Thus only $(5 \%)$ who got good score. This indicated that the students have not got satisfying score.

\subsection{The Analysis of the Data Collected Through the Questionnaire.}

The questionnaire distributed to the students consists of the items. We will find the result of the questionnaire as well the description of each item as follows: 
Table 3. The students Opinion About English Main Course

\begin{tabular}{llll}
\hline No. & Classification & Frequency & Percentage \\
\hline 1 & Very Agree & 18 & $45 \%$ \\
2 & Agree & 16 & $40 \%$ \\
3 & Fairly & 8 & $15 \%$ \\
4 & Disagree & 0 & 0 \\
5 & Strongly Disagree & 0 & 0 \\
\hline & Total & 40 & $100 \%$ \\
\hline
\end{tabular}

Source : Questionnaire, item I

The table indicates that it can be concluded the motivation of the first year students of Aribusiness State Politechnic of Pangkajene Kepulauanin learning English is high.

Table 4. The Frequency of the Teacher Introduce and Teaching Adverb When Still in the First Year Students

\begin{tabular}{llll}
\hline No. & Classification & Frequency & Percentage \\
\hline 1 & Always & 3 & $7,5 \%$ \\
2 & Sometimes & 9 & $22,5 \%$ \\
3 & Seldom & 12 & $30 \%$ \\
4 & Ever & 12 & $30 \%$ \\
5 & Never & 4 & $10 \%$ \\
\hline & Total & 40 & $100 \%$ \\
\hline
\end{tabular}

Source; Questionnaire, item 2

The table indicates that the frequency of the teacher introduces and teaching adverb when the students still in the first year is seldom.

Table 5. The Frequency of the English Teacher giving Assignment to the Students in Adverb

\begin{tabular}{llll}
\hline No. & Classification & Frequency & Percentage \\
\hline 1 & Always & 5 & $45 \%$ \\
2 & Sometimes & 20 & $32,5 \%$ \\
3 & Seldom & 9 & $12,5 \%$ \\
4 & Ever & 4 & $10 \%$ \\
5 & Never & 2 & 0 \\
\hline & Total & 40 & $100 \%$ \\
\hline
\end{tabular}

Source ; Questionnaire, item 4

From response of the students in the table above, it can conformed that the frequency of the English. teacher at Agribusiness State Politechnic of Pangkajene Kepulauanin giving back the assignment after being corrected is high, how ever, the students was not give good attention to the result of the their assignment.

Table 6. The Teacher Frequency Re-explaining the Students assignment (homework) about adverb after they corrected

\begin{tabular}{llll}
\hline No. & Classification & Frequency & Percentage \\
\hline 1 & Always & 11 & $27,5 \%$ \\
2 & Sometimes & 16 & $40 \%$ \\
3 & Seldom & 10 & $25 \%$ \\
4 & Ever & 2 & $5 \%$ \\
5 & Never & 1 & $2,5 \%$ \\
\hline
\end{tabular}


Source ; Questionnaire, item 5

The table above showed that the English. Teacher of the school in explain their students assignment after they corrected is high. This proved by 16 the students or $40 \%$, who states sometimes and 11 or $27,5 \%$, who stated always. However, the students passably did not take care about the result of their work.

Table 7. The Students Opinion About the Level Difficulty in Learning Adverb

\begin{tabular}{llll}
\hline No. & \multicolumn{1}{c}{ Classification } & Frequency & Percentage \\
\hline 1 & Very Difficulty & 3 & $7,5 \%$ \\
2 & Difficulty & 18 & $45 \%$ \\
3 & Parley Difficulty & 13 & $32,5 \%$ \\
4 & Easy & 6 & $15 \%$ \\
5 & Very Easy & 0 & $0 \%$ \\
\hline & Total & 40 & $100 \%$ \\
\hline
\end{tabular}

Source ; Questionnaire, item 6

From the students' responses in the table above, we can say that the students' found it difficulty in lean the English adverb.

Table 8. The Students Opinion About the Books Prepared in the Library Especially Adverb

\begin{tabular}{llll}
\hline No. & Classification & Frequency & Percentage \\
\hline 1 & Very Sufficient & 2 & $5 \%$ \\
2 & Sufficient & 18 & $45 \%$ \\
3 & Fairly Sufficient & 12 & $30 \%$ \\
4 & Not Sufficient & 5 & $12,5 \%$ \\
5 & Extremely Not Sufficient & 3 & $7,5 \%$ \\
\hline & Total & 40 & $100 \%$ \\
\hline
\end{tabular}

Source; Questionnaire, item 7

By looking over the table above, it can be concluded that the books prepared in the library at their schools especially adverb materials are sufficient. In the next item we will see their frequency in reading English books especially adverb.

Table 9. The Frequency in Reading Books or Literature that Discuss the English Adverb

\begin{tabular}{llll}
\hline No. & Classification & Frequency & Percentage \\
\hline 1 & Always & 0 & $0 \%$ \\
2 & Sometimes & 5 & $12,5 \%$ \\
3 & Seldom & 12 & $5 \%$ \\
4 & Ever & 14 & $35 \%$ \\
5 & Never & 19 & $47,5 \%$ \\
\hline & Total & 40 & $100 \%$ \\
\hline
\end{tabular}

Source; Questionnaire, item 8

The table above shows that the frequency of the students reading books that discuss the adverb are very low, if we see their ability, the writer infers that the one factor may influencing their poor score in using adverb because the lock reading even the book prepared in the library are Sufficient. 
Table 10. The Students Opinion about the Technique of the English Teacher in Teaching Adverb

\begin{tabular}{llll}
\hline No. & Classification & Frequency & Percentage \\
\hline 1 & Very Good & 12 & $30,5 \%$ \\
2 & Good & 22 & $55 \%$ \\
3 & Fairly Good & 3 & $7,5 \%$ \\
4 & Not Good & 3 & $7,5 \%$ \\
5 & Extremely Not Good & 0 & $0 \%$ \\
\hline & Total & 40 & $100 \%$ \\
\hline
\end{tabular}

Source ; Questionnaire, item 5

Based on the table above shows that the technique used by the teacher in teaching adverb are good. But the students may not give pay attention seriously that their teacher has explained, in fact. They cannot using the "adverb".

Table 11. The Frequency of the Teacher Giving Material

\begin{tabular}{llll}
\multicolumn{5}{c}{ With Example About Adverb } \\
\hline No. & Classification & Frequency & Percentage \\
\hline 1 & Always & 14 & $35 \%$ \\
2 & Sometimes & 13 & $32,5 \%$ \\
3 & Seldom & 5 & $12 \%$ \\
4 & Ever & 8 & $20 \%$ \\
5 & Never & - & - \\
\hline & Total & 40 & $100 \%$ \\
\hline
\end{tabular}

Source; Questionnaire, item 10

Based on the table above, it can be concluded that most of the student stated that the teacher giving materials and she example about adverb are high. It means that their teacher have tried to prepare the materials as well as possible. But the students may not pay attention seriously what their teacher has explained.

After analyzing the data, the writer would like to present the discussion of the result of the data analysis, this discussion of the result of the data analysis; this discussion aims at describing the students' ability in using English adverb and the factors which might have influenced the student's achievement.

\subsection{The Students Ability in Using English Adverb}

With references to the ability data analysis of the test, it is found that the students' ability in English adverb is classified "poor". This is proven by the result of students mean score is 4,65 . However, there is no harm for the students in trying to increase this good ability into the highest mark. This mean that in order the students can develop their low score or achievement in English adverb, they are accepted to learn them more effectively and seriously.

\subsection{The Factors that Hamper the Students in Using English Adverb}

Considering the data analyzed of the questionnaire, it is also found that the firstyear students of Agribusiness State Polytechnic of Pangkajene Kepulauanface problems in English adverb; this is proved in tables in which most of them state that they face difficulty in English adverb. In fact, it indicated that the students account 
some problems in English adverb. Here the writer presents the students' problem that the student also find difficulty adverb in sentences.

\section{Conclusion} as follows:

Based on the presentation above, the writer would like to present the conclusion

The first-year students of Agribusiness State Polytechnic of Pangkajene Kepulauan considered to be less creative. None of them gave any comments about their problems in using English, although they have been given chance for it.

The students' achievement in using English adverbs at Agribusiness State Politechnic of Pangkajene Kepulauan still classified as a low achievement. The students of the Agribusiness State Polytechnic of Pangkajene Kepulauan had only average score 4,65. It can only be classified into the poor score.

The low of the first-year students' achievement in using English is caused by many factors. The factors that may influence their achievement are their interest, activities in learning adverbs, their assignments whether schoolwork or homework. The methods used by the English teacher were also very influential for the students. The English teacher has to try to examine the students' assignments to attract their interest in studying English.

\section{References}

Arsyad, Azhar. Your Basic Vocabulary. Yogyakarta: Pustaka Pelajar.

Djauhari, imam, (1986). Mastery on English Parts of Speech. Surabaya: Indah

Depdikbud. (1995). Petunjuk Pelaksanaan Proses Belajar Mengajar dan Petunjuk Pelaksanaan Sistem Penilaian. Jakarta: Depdikbud.

Frank, Marcella. (1972). Modern English. New York : Prentice Hall Inc.

Gay, L. R. (1981). Educational Research : Competencies for Analysis and Applications (2 th. Ed.) Columbus Chio : Charles E Merric Publishing Company.

Hartanto, Jhon. S. Drs. (1996). ABC English Grammar. CV. Bintang Pelajar.

Hornby, A.S. (1975). Guide to Patterns and Usage in English. London, Oxford University.

Huddleston, Rodney D. (2005). A Student's Introduction to English Grammar, Oxford University.

Kneller, Goerge, F. Logis and Language Education. New York. Jhon W. Ley and Sons, Inc.

Mufida, Anrozi. Standard of English Grammar. Jatim. CV. Bandung.

Sudjono, (1995), Prosedur Penelitian.

Scott, F.S. (1976). A Linguistic Study of its Classes and Structures. London, Heinemann Educational Books. Ltd..

Thomson, A.J. and A.V. Marnet. (1986). A Practical English Grammar. London. Oxford University Press. 